\title{
Research on Flipped Classroom Instructional Design Oriented the Cultivation of Subject Consciousness
}

\author{
Ma Xiulin ${ }^{1}$, Liang Jing ${ }^{1}$, Li Sheng ${ }^{2} \&$ Liu Jingjing ${ }^{1}$ \\ ${ }^{1}$ Faculty of Education, Beijing Normal University, Beijing, China \\ ${ }^{2}$ The Joint Laboratory for Mobile Learning (Ministry of Education - China Mobile Communication Corporation), \\ Beijing, China \\ Correspondence: Ma Xiulin, Faculty of Education, Beijing Normal University, Beijing, China.
}

Received: March 26, 2019

doi:10.11114/ijsss.v7i3.4222
Accepted: April 18, $2019 \quad$ Available online: April 22, 2019

URL: https://doi.org/10.11114/ijsss.v7i3.4222

\begin{abstract}
The information age puts forward higher requirements for talent cultivation, and talents with independent learning concept and innovative spirit are urgently needed. As an activity of cultivating people, education plays an important role in promoting students' participation and cultivating students' subject consciousness, while Flipped Classroom provides a new way for that. This study combines the cultivation of subject consciousness with the practice of Flipped Classroom. Firstly, by analyzing the literature, three dimensions of subject consciousness are concluded: self-consciousness, social consciousness and practice consciousness, and the activities, strategies and evaluation of flipped teaching are designed. Then, the flipped mode and instructional design are applied to the teaching of public computer courses, which experienced two rounds of teaching practice. Finally, by comparing the experimental group with the control group and the longitudinal comparison of the time series, it is found that the flipped mode can effectively stimulate students' subject consciousness, and there is an obvious symbiotic relationship between the students' subject consciousness and performance; and it forms the strategy and effective model of cultivating students' subject consciousness.
\end{abstract}

Keywords: subject consciousness, flipped classroom, instructional design

\section{Introduction}

\subsection{Research Background}

As a kind of social practice to cultivate people, education is responsible for improving the students' subjectivity and subject consciousness. Since last century, each country has attached great importance to the cultivation of students' subject consciousness. For example, Japan proposed to cultivate "Japanese with subject consciousness" as their educational goal. South Korea emphasized the concept of "whole person" in educational goals, which intend to cultivate "healthy, independent and creative people". Since the 1990s, the education trend of "subjective education" has emerged in China which emphasizing on the potential and ability development of each individual. However, due to the limitations of traditional educational thoughts and evaluation mechanism, there are still many educational phenomena that ignore students' subjectivity in some classroom. The phenomena include dull classroom atmosphere, less independent learning time, lower awareness of innovation and problem-solving ability. If students do not learn how to learn, it is difficult to adapt to the changing environment and keep pace with the age.

The New Curriculum Reform (Chinese) gradually emphasizes the cultivation of students' subject consciousness. In the outline of Curriculum Reform of Basic Education issued by China, the concept of "people-oriented" and "student-oriented" has been repeatedly reiterated. For example, the specific goal of the reform requires students to develop an active learning attitude, including to avoid rote learning and mechanical training, to develop students "learn to learn" ability and problem-solving, and to emphasize the cultivation of students' independence and autonomy. All these goals reflect the requirement of cultivating students' subject consciousness.

Flipped Classroom is an innovation of the relationship between teaching and learning in the context of information technology. It has aroused extensive discussion and practice around the world since it came out. It turns the traditional classroom "teachers explain in class, students exercise after-school " into "students self-study before class, exercises in class", it is special in the changing of teaching process, the knowledge construction process is essentially in the 
classroom, and the stage of knowledge teaching is before class. Students are free to watch video before class and ask questions to their peers or teachers at any time in class. Flipped Classroom gives teachers and students more opportunities for communication.

The root cause for the improvement of students' external learning performance and classroom participation and enthusiasm in Flipped Classroom, lies in the enhancement of students' subject consciousness. When students regard themselves as the subject of the learning process and truly feel that they have independent control over the whole learning process, they can give full play to their initiative and actively participate in learning activities. Combined with the innovation and advantages of Flipped Classroom in teaching form, Flipped Classroom can be regarded as a new way to realize the goal of New Curriculum Reform and cultivating students' subject consciousness.

\subsection{Research Questions}

This study hopes to draw on the current studies on student subject consciousness and Flipped Classroom to verify and explore how to further cultivate students' subject consciousness through Flipped Classroom. Based on the research purpose and main contents, the key problems to be solved in the research are as follows.

(a). Analyzing the convergence of subject consciousness and Flipped Classroom in theory, and expound the internal connection between Flipped Classroom and subject consciousness.

(b). Constructing the Flipped Classroom teaching mode oriented the cultivation of subject consciousness. After defining the connotation and connection between Flipped Classroom and subject consciousness, the Flipped Classroom teaching mode oriented on subject consciousness cultivation would be constructed.

(c). Designing and developing of teaching activities and processes. Combining with the teaching content of the public computer courses of Beijing Normal University, the research will carry out the teaching activities and strategy design, and verify and revise the proposed strategy, and evaluate the effect of teaching practice comprehensively. The relationship between Flipped Classroom and the cultivation of subject consciousness should be clarified from the practical level.

\section{Literature Review}

\subsection{Subject Consciousness}

\subsubsection{Related Research}

The development of students' subjectivity depends on two aspects: one is the promoting effect of external environment, and the other is students themselves, namely the subject consciousness. Subject consciousness refers to the external expression of human's ideas of autonomy, initiative and creativity, and is a kind of conscious consciousness of human's own status, ability and value (Huang, 2007). Subject consciousness can control the purpose, plan, scheme and implementation process of subject practice. The subject consciousness is the internal driving factor for the development of students' subjectivity, and it is the embodiment of students' subjectivity at the level of consciousness. Moreover, subject consciousness must be reflected through practical activities, which means that only if we discuss students' subject consciousness in education and teaching activities, can the subject consciousness be reasonable.

There are abundant researches and practices abroad in terms of independent learning and cultivating students' independent learning ability. The concept of "independent learning" was formally proposed by Henir Holec in the 1980s. Subsequently, researchers carried out the assumption and practice of cultivating students' independent learning ability from multiple perspectives such as curriculum setting, classroom teaching and learning strategy training in teaching practice. Murray, Lee, Hart and others have adopted a variety of strategies in classroom teaching to promote students' independent learning, including encouraging and assisting learners to make learning plans according to their own conditions, providing rich learning resources, group learning, and requiring students to conduct self-evaluation and reflection in diary and other ways (Xu \& Zhan, 2004). Victori and Lockhart enhanced students' independent learning ability through learning strategy training courses. The specific measures included: investigating the current situation of students' ability, carrying out targeted strategy demonstration and training, and monitoring learners' use of learning strategies (Victori \& Lockhart, 1995). The above strategies and practices lay a foundation for solving the problem of "how to cultivate students' subject consciousness in classroom teaching".

In China, with the increasingly serious constraint of traditional education on students, subjectivity education has received continuous attention of educational experts. Since the 1990s, a number of large-scale subjectivity education experiments have emerged in China. Beijing Normal University and Renmin Avenue Primary School in Anyang, Henan province jointly carried out the "primary students' subjectivity development experiment", aiming to explore how to truly realize the "cultivation of students' consciousness and ability of subject participation", and carried out teaching practice from the characteristics of independence, initiative and creativity (Pei, 2000). Sichuan Chenghua District, Hubei 
Jingmen and other places have also launched the primary and secondary student's subjective quality training experiments, number of outstanding teaching cases has emerged.

It can be seen from the development status at home and abroad that the "student-centered" and "focusing on students' own development" have been the core topics in the education field. The idea of subjectivity education permeates the concepts related to information technology such as "integration of information technology and curriculum", "online learning", "mixed learning" and "Flipped Classroom". Therefore, it is of great significance for education reform to pay attention to students' subject consciousness and the embodiment of this in the new teaching method.

\subsubsection{Teaching Strategies in the Practice of Subjectivity Education}

Since the large-scale practice of subjectivity education emerged in the 1990s, Beijing Normal University formally established the "Developmental Teaching Laboratory" in order to further practice the idea of subjectivity education. The developmental teaching has been carried out in many parts of the country, and some effective strategies have been summarized gradually, such as paying attention to relaxed, democracy, creating problem situation, guiding students' thinking, paying attention to individual differences, etc (Thomson, Masumi, \& Osho, 2001). Zhang Yue, on the other hand, combined some teaching strategies of subject participation with English teaching, and proposed the specific teaching strategies of constructing subject participation teaching in English class (Zhang, 2013). Those strategies are respecting differences, stimulating students' interest in participation, and reflecting the effect of students' participation in various activities.

By analyzing the existing teaching strategies, it can be found that researchers and teachers usually stimulate students' initiative from the classroom atmosphere, teaching activities and results. The specific measures are as follows.

(a). Create the atmosphere of subject participation to wake up the students' subject consciousness, which is an important premise to improve students' subjectivity. The key to creating an atmosphere of subject participation lies in the change of teachers' teaching concepts. Teachers should treat students as equal individuals and give them full opportunities for dialogue.

(b). Create rich teaching activities to stimulate students' interest in participation, which can promote the participation of students and improve students' subject awareness directly. It is the essential part to combine teaching activities closely, design teaching around students, and develop rich and effective teaching activities.

(c). Provide opportunities to present learning results, and maintain the subject participation to form a virtuous cycle.

\subsection{Flipped Classroom and Its Impact on Talent Cultivation}

The Flipped Classroom is also known as The Flipped Learning. Researchers have conducted research on "what is Flipped Classroom" and "what is flipped by Flipped Classroom" since The Flipped Classroom was widely promoted.

\subsubsection{Research on Organizational Strategy of Flipped Classroom}

A group of teachers and researchers in China also carried out practical activities of Flipped Classroom and expounded its implementation effect. Chongqing Jukui Middle School combines Flipped Classroom with the original efficient classroom mode and proposed the specific implementation methods of Flipped Classroom: three "flipped", four links before class, five steps in class and six advantages. Shandong Changle First Middle School also puts forward its own flipped teaching mode -- "two stages, four steps and ten links" based on the Flipped Classroom mode abroad. In higher education, Ma Xiulin, Zhao Guoqing and others carried out the flipped practice with the public computer courses of Beijing Normal University (Ma, Zhao, \& Wu, 2013). The practical results show that Flipped Classroom puts forward higher requirements for both teachers and students, and students with weak foundation are not suitable for this form, which means excellent students and intermediate students may be more suitable for learning in Flipped Classroom.

\subsubsection{Research on the Educational Value of Flipped Classroom}

As the birthplace of Flipped Classroom, Flipped Classroom has been promoted and implemented on a large scale in the United States. There are relatively more successful Flipped Classroom cases, which are dominated by science and engineering courses such as mathematics and chemistry. Bill Tucker, an American scholar, launched a Flipped Classroom for the Office Excel course. His practice has proved that the Flipped Classroom can give hard-working middle school students and excellent students equal opportunities to participate in the class. And this new education form not only can improve their learning enthusiasm, but also improve their performance rapidly (Bill \& Tucker, 2012). After the implementation of Flipped Classroom, Mark Frydenberg believed that Flipped Classroom changed the focus of classroom to problem-solving (Mark \& Frydenberg, 2012). Another advantage of Flipped Classroom proposed by Clyde and Nancy is that the teachers can more accurately grasp the knowledge blind spots of the students through the questions from the students (Clyde, Herreid, \& Nancy, 2013).

Based on the existing research, we can only conclude that students' performance might be improved through Flipped 
Classroom, but it needs time to prove. However, according to the questionnaire for students and teachers, Flipped Classroom can improve students' independent learning ability and improve their enthusiasm and creativity. In fact, what is really helpful for students in Flipped Classroom is the improvement of students' subject consciousness in the learning process. No matter learning enthusiasm, independent learning ability or innovation, they can only be demonstrated under the premise of strengthening students' subject consciousness. And the improvement of academic performance is bound to bring the change of attitude, method, motivation and other internal factors, which can also be attributed to the students' subject consciousness.

\section{Research Design}

\subsection{Research Objectives}

This study aims to explore how to cultivate students' subject consciousness through Flipped Classroom from the theoretical and practical aspects.

From the perspective of theory, firstly by reviewing the existing researches on subjectivity education and subject consciousness, and the connotation and external expression of subject consciousness are concluded. And then combined it, combined with the Flipped Classroom to illustrate the natural advantages of Flipped Classroom in cultivating students' subject consciousness. After grasping the connotation of subject consciousness, the evaluation index of subject consciousness will be constructed in combination with practical teaching. Secondly, according to the cultivation strategy of subject consciousness and the characteristics of Flipped Classroom, the Flipped Classroom teaching mode oriented the cultivation of subject consciousness will be constructed.

From the perspective of practice, the above teaching mode is designed and developed in detail in combination with specific courses, and verified in teaching practice. Through real-time tracking and recording of the learning situation and performance of students in the experimental class, the data is quantified according to the evaluation scheme and subject consciousness questionnaire. Based on the collected data, the mode and strategies will be verified to judge whether the teaching objectives are achieved and improve students' subjective consciousness.

\subsection{Research Procedure}

The research process of this study mainly includes four stages: analysis, design, development, implement and evaluation. Each stage contains one or two specific research objectives, and the research framework is shown in Figure 1.

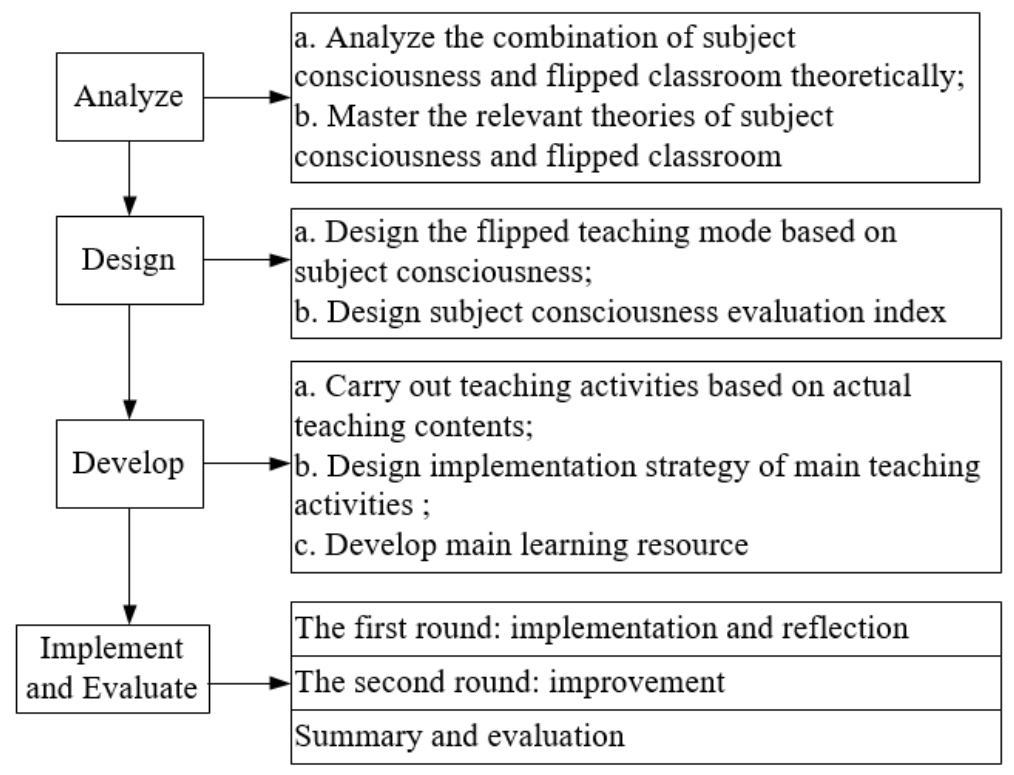

Figure 1. Research procedure

\section{Flipped Classroom Instructional Design Oriented the Cultivation of Subject Consciousness}

\subsection{Flipped Classroom Teaching Mode Analysis}

Incorporating subject consciousness into the Flipped Classroom is the focus and innovation of this research. Therefore, the dimensions and evaluation indexes of subject consciousness should be explained to clarify the dimensions, connotation and specific representation of subject consciousness, and then combine with the Flipped Classroom to 
complete the design of Flipped Classroom teaching mode oriented on the cultivation of subject consciousness.

\subsubsection{The Dimension of Subject Consciousness}

Zhang Jianyun used static abstract analysis method philosophically, and divided the connotation of the subject consciousness into the following six aspects: autonomy consciousness, practice consciousness, innovative consciousness, citizen consciousness, personality consciousness, and passivity consciousness (Zhang, 2002). Citizen consciousness refers to "a kind of consciousness in which people consciously show their subject power in the relationship between subject and object"; passivity consciousness refers to that people admit limitations that exist in practice and tries to recognize and grasp the awareness of these limitations. Analyzing the above six dimensions carefully, the sense of autonomy consciousness and personality consciousness is derived from people's understanding of their own status; practice consciousness, passivity consciousness and innovation consciousness happen when people transform the outside world; citizen consciousness comes from the process of man's relationship with society and others.

In the field of education, the "primary students' subjectivity development experiment" hosted by professor Pei Dina of Beijing Normal University has made a profound impact on basic education in the 1990s. One of the experimental results is that established and extended the "primary students' subjectivity development indexes system". the subjectivity was divided into four basic characteristics: "autonomy, initiative, creativity and sociality", and subdivided into 10 analysis units (Zheng, Yu, \&Nan, 2009). On the basis of professor Pei's research, Dai Zhongxin reclassified students' subjective traits and added trait layer and analysis unit (Dai \& Liu, 2010).

Based on multi-angle analysis of the subject consciousness connotation in the field of philosophy and combining the logical and real structure of subject consciousness, this study focuses on the different attributes of the structure of subject consciousness, and divides subject consciousness into self-consciousness, practice consciousness and social consciousness according to the framework of "man's own attribute - man's transformation of the outside world- man's relationship with the outside world", and subdivides them into different analysis units. As is shown in Figure 2.

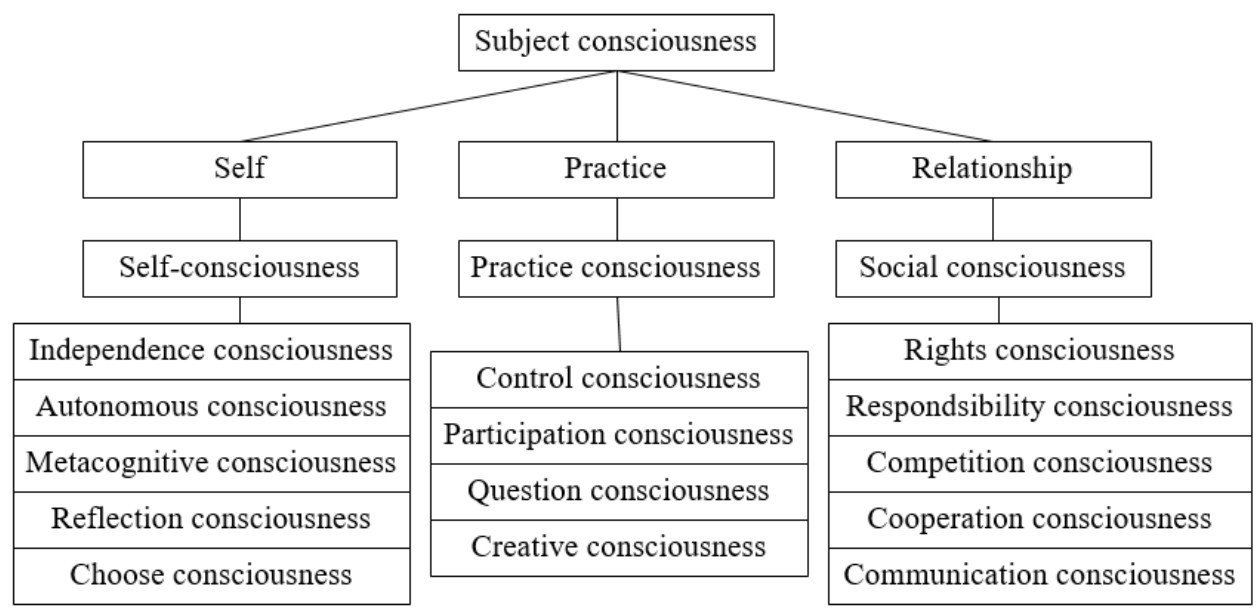

Figure 2. subject consciousness evaluation indexes

\subsubsection{Flipped Classroom Teaching Mode Design}

In this study, the Flipped Classroom was divided into two stages, pre-class and in-class according to professor Robert Talbert's division method (Robert, 2010). According to the characteristics of learning new knowledge before class and internalizing knowledge in class, the two stages are named "learning stage of new knowledge before class" and "sharing and promoting stage in class". Among them, the sharing and promoting stage in class is divided into the knowledge discussion and sharing and the summary and promoting of teachers supported by various teaching activities. Therefore, referring to the existing Flipped Classroom teaching mode and combining with the evaluation indexes of students' subject consciousness, this study designs the Flipped Classroom teaching mode. As is shown in Figure 3. 


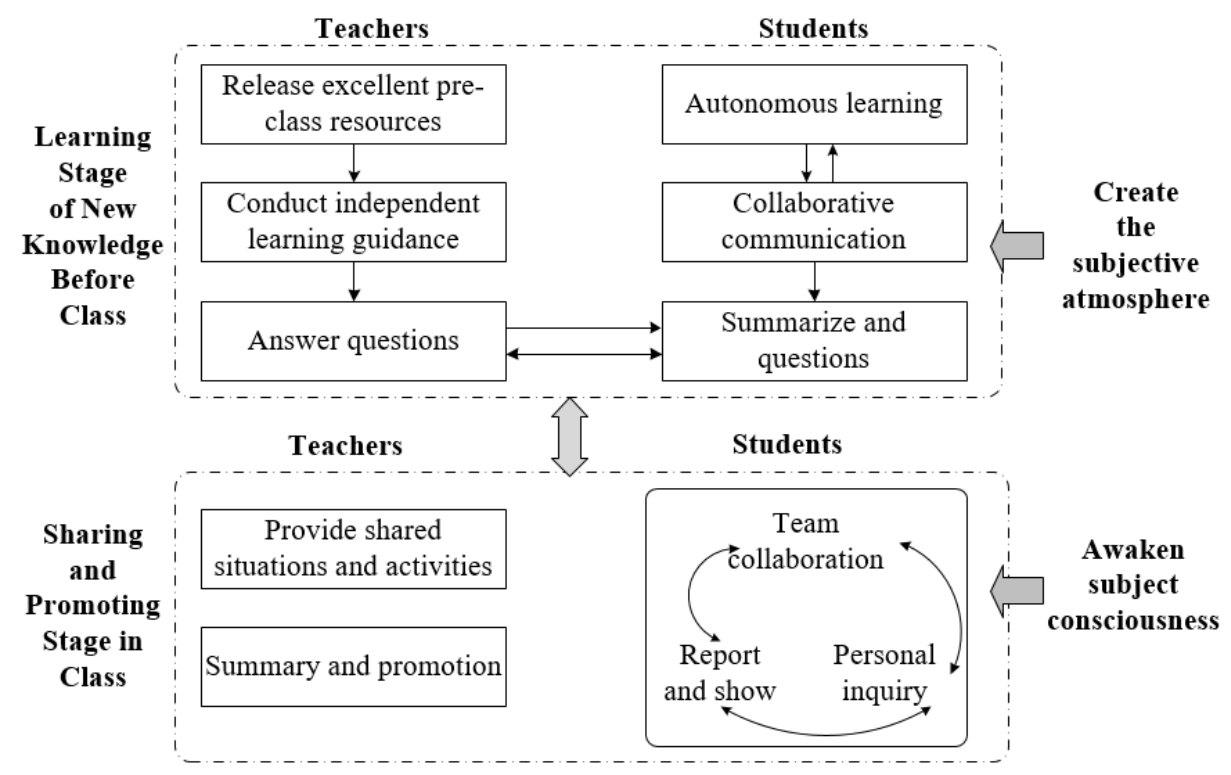

Figure 3. Flipped classroom teaching mode oriented on the cultivation of subject consciousness

\subsection{Flipped Classroom Instructional Design}

Flipped Classroom has great flexibility, which is reflected in the close combination of teaching activities and teaching contents. Teachers should evaluate what content is suitable for flipped teaching and what for direct teaching, and design corresponding teaching activities according to different teaching contents.

\subsubsection{Teaching Content and Object Analysis}

This research is mainly based on two courses of Beijing Normal University, namely Multimedia Technology and Web Design and Information Processing Foundation.

Multimedia Technology and Web Design course includes the basic concept of multimedia, image processing, audio and video processing and simple web page production. Information Processing Foundation course includes basic computer knowledge, Office software and knowledge and skills related network. Both of the two courses are practical courses with emphasizing on theoretical basis and operational skills. The course content is usually arranged in the form of special topics, which is suitable for project-based, task-based and other inquiry-based teaching.

The teaching object is the freshman of Beijing Normal University, who have certain independent learning ability and possessiveness. In addition, most students have learned relevant basic knowledge in junior and senior high school, but there is a certain gap. Therefore, the gap between students of different levels in different classes should be fully considered to provide support for their development respectively in the process of instructional design.

\subsubsection{Teaching Activities Analysis}

The focus of teaching practice is how to carry out these teaching activities to make students really "move", that is, how to combine the course content and teaching activities, and which specific strategies are used to maximize the effect of teaching activities. In order to arouse students' subject consciousness in different dimensions, the teaching strategies used by the researchers are shown in Table 1

\begin{tabular}{|c|c|c|c|c|}
\hline \multicolumn{2}{|c|}{$\begin{array}{l}\text { Subject consciousness } \\
\text { Flipped Classroom }\end{array}$} & $\begin{array}{l}\text { Self- } \\
\text { consciousness }\end{array}$ & Practice consciousness & Social consciousness \\
\hline \multirow{2}{*}{$\begin{array}{l}\text { Learning Stage } \\
\text { of New } \\
\text { Knowledge } \\
\text { Before Class }\end{array}$} & Autonomous learning & $\begin{array}{l}\text { Clear learning task; } \\
\text { Track network behavior; } \\
\text { Feedback in time }\end{array}$ & & \\
\hline & Collaborative learning & Role awareness & Role assignment & Role assignment \\
\hline \multirow{4}{*}{$\begin{array}{l}\text { Sharing and } \\
\text { Promoting } \\
\text { Stage in Class }\end{array}$} & Group discussion & Role awareness & Role assignment & Role assignment \\
\hline & Group report & Reward the initiative & Encourage innovation & \\
\hline & Evaluation & $\begin{array}{l}\text { Reflect and } \\
\text { self-assessment }\end{array}$ & $\begin{array}{l}\text { Mutual-assessment and } \\
\text { questioned }\end{array}$ & $\begin{array}{l}\text { Mutual-assessment and } \\
\text { questioned }\end{array}$ \\
\hline & Teacher summary & Direct reflection & & \\
\hline
\end{tabular}

. The first row in the table represents the three dimensions of subject consciousness. The first column is the two stages of Flipped Classroom; and the second column is the main teaching activities in each stage. The middle part represents 
the teaching strategies adopted in the corresponding teaching activities to cultivate a certain subject consciousness. The unfilled tables only represent that no additional teaching strategies are applied, but doesn't mean this teaching activity is unable to manifest certain subject consciousness.

Table 1. Flipped Classroom instructional design oriented the cultivation of subject consciousness

\begin{tabular}{|c|c|c|c|c|}
\hline \multicolumn{2}{|c|}{$\begin{array}{l}\text { Subject consciousness } \\
\text { Flipped Classroom }\end{array}$} & $\begin{array}{l}\text { Self- } \\
\text { consciousness }\end{array}$ & Practice consciousness & Social consciousness \\
\hline \multirow{2}{*}{$\begin{array}{l}\text { Learning Stage } \\
\text { of New } \\
\text { Knowledge } \\
\text { Before Class }\end{array}$} & Autonomous learning & $\begin{array}{l}\text { Clear learning task; } \\
\text { Track network behavior; } \\
\text { Feedback in time }\end{array}$ & & \\
\hline & Collaborative learning & Role awareness & Role assignment & Role assignment \\
\hline \multirow{4}{*}{$\begin{array}{l}\text { Sharing and } \\
\text { Promoting } \\
\text { Stage in Class }\end{array}$} & Group discussion & Role awareness & Role assignment & Role assignment \\
\hline & Group report & Reward the initiative & Encourage innovation & \\
\hline & Evaluation & $\begin{array}{l}\text { Reflect and } \\
\text { self-assessment }\end{array}$ & $\begin{array}{l}\text { Mutual-assessment and } \\
\text { questioned }\end{array}$ & $\begin{array}{l}\text { Mutual-assessment and } \\
\text { questioned }\end{array}$ \\
\hline & Teacher summary & Direct reflection & & \\
\hline
\end{tabular}

(1) Learning stage of new knowledge before class

(a) Independent learning -- Students are in charge, teachers play the role of guidance, supervision in the independent learning activities. Students need to independently choose and complete learning tasks according to their own foundation and materials provided by teachers. In the learning process, they need to reflect on their learning at any time and carry out a higher level of cognition and regulation on the cognitive in the learning process. Self-consciousness includes autonomy, independence, reflection, choice and metacognitive consciousness, etc. The pre-class independent learning activities of Flipped Classroom match these characteristics exactly. In addition, the learning process will inevitably involve practice, which belongs to the category of "doing" and has to do with practice consciousness. When teachers and students communicate with each other about problems encountered in learning, interpersonal interaction will occur, which reflects social consciousness.

(b) Collaborative learning -- Collaborative learning can reflect students' social consciousness and practice consciousness more obviously. In the group cooperation, the self-examination and behavior regulation of the members can reflect the self-consciousness.

(2) Sharing and Promotion Stage in Class

(a) Group discussion -- Group discussion is a kind of collaborative learning. In the group discussion, students have not only the space for independent thinking, but also the atmosphere and opportunities for communication. Students need to fully express their ideas, exchange ideas with their peers, and negotiate and compromise when necessary. In this process, students' social consciousness can be effectively cultivated.

(b) Group presentation -- Group report can reflect the students' self- consciousness and practice consciousness. Teachers should pay attention to cultivate students' abilities involved in reporting, such as language expression, logic of reporting, presentation form and sequence of contents.

(c) Evaluation -- Evaluation includes students' self-evaluation, students' mutual evaluation and teachers' evaluation. All evaluation activities should follow the principle of objectivity and impartiality. The evaluation activities can reflect students' self-consciousness, social consciousness and practice consciousness.

(d) Teacher summary -- Teacher summary activity is led by the teacher. Summary stage requires teachers to be able to summarize the knowledge system from a strategic perspective, correct students' misunderstanding. Summary to consciously guide students to reflect on the review of the knowledge of the correct understanding.

\subsubsection{Evaluation Methods Analysis}

(1) Common strategies for Flipped Classroom teaching evaluation

The Flipped Classroom in this study adopted the method of combining summative evaluation and formative evaluation, and attached importance to the evaluation of students' continuous and dynamic learning process, learning ability and thinking progress. The evaluation methods used in this study are as follows:

(a) Self-evaluation -- Self-evaluation in this study is carried out from two aspects: one is to ask students to consciously and actively evaluate their own independent learning, learning task completion, and understanding of knowledge points; the other is to fill in the subject consciousness questionnaire. The questionnaire will be issued at the beginning of the semester and at the end of the semester.

(b) Group mutual evaluation and intra-group mutual evaluation -- Group mutual evaluation is based on the group to evaluate each group's learning task completion, report and presentation results. Intra-group mutual evaluation is the 
evaluation made by team members on their contribution, participation and cooperation in completing tasks.

(c) Teachers' evaluation -- Teachers can conduct comprehensive evaluation on students from pre-class independent learning, classroom performance, report and presentation, homework completion and other aspects.

(2) Subject consciousness questionnaire development

In order to understand whether students' subject consciousness changes before and after participating in Flipped Classroom, and verify whether Flipped Classroom teaching to cultivate students' subject consciousness, the authors compiled the "subject consciousness questionnaire", and investigated students' subject consciousness from three dimensions: self-consciousness, practice consciousness and social consciousness.

The questionnaire referred to several indexes which were formulated by professor Pei Dina in "experimental research on primary and secondary school students' subjectivity education", and combined with the reality, finally formed 27 questionnaire questions. Likert's five-point method was used to express the values of each item in the questionnaire. After the questionnaire was completed, it had been reviewed and modified by many scholars, and it has a good expert structure validity. In the removal of the personal information in the questionnaire, Cronbach's Alpha was used to test the reliability of 65 questionnaire data collected in the prediction test, the overall internal consistency of the questionnaire and three dimensions of their respective internal consistency were greater than 0.8 . The specific data is shown in Table 2 . The questionnaire reliability index is good, and has the high reliability.

Table 2. Prediction reliability of the questionnaire

\begin{tabular}{ll}
\cline { 2 - 2 } Items & Cronbach's Alpha \\
\cline { 2 - 2 } Global consistency & 0.947 \\
Self- consciousness & 0.903 \\
Practice consciousness & 0.853 \\
Social consciousness & 0.876 \\
\cline { 2 - 2 } 4.2.4 Independent Learning &
\end{tabular}

The independent learning resources provided to students in this study mainly include four types: micro video, text, learning task list, material and expansion resources. The relationships and functions of these resources are shown in Figure 4.

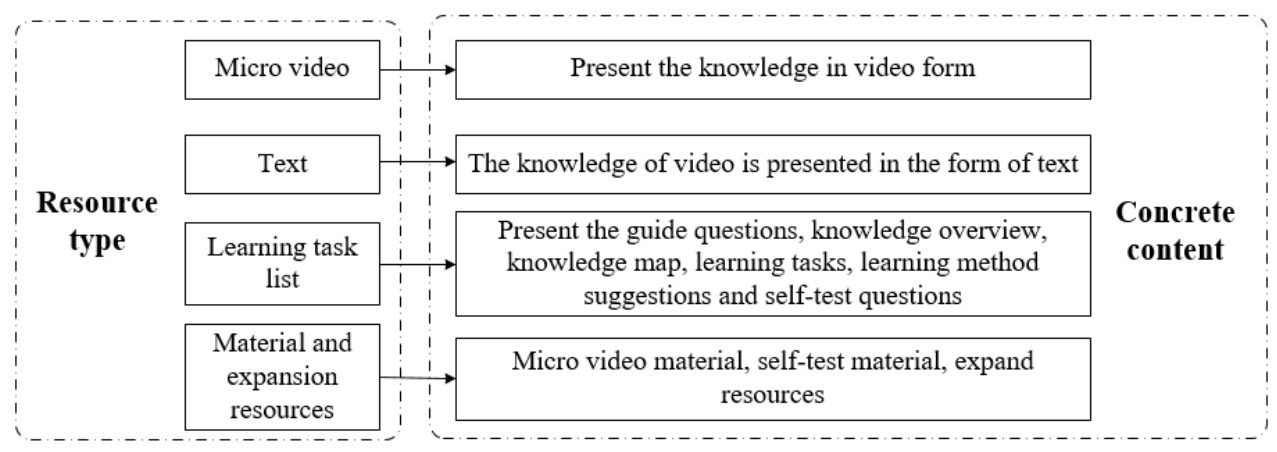

Figure 4. Relationships diagram of independent learning resource

\section{Implementation and Evaluation of Flipped Classroom Teaching Activities}

\subsection{The First Round of Teaching Practice}

\subsubsection{Research Object Selection}

The questions to be explored in the first round are as follows: (a) verify the feasibility of Flipped Classroom instructional design oriented on subject consciousness cultivation; (b) verify whether Flipped Classroom can have a significant impact on student performance.

Based on Multimedia Technology and Web Design, this round carried out in the mode of "experimental class and control class", and the development of "subject consciousness" was compared horizontally through different teaching modes. The course is a compulsory course for the students with 4 periods per week, 2 periods of which are conducted in the multimedia classroom in the form of demonstration and discussion, and the other 2 periods of which require students to design specific works independently or cooperatively in the computer room. This round is supported by the " Learning Cell System" online learning platform of Beijing Normal University.

5.1.2 Teaching Activities Implementation 
Before the beginning of the flipped experiment, teachers should introduce to students the source of Flipped Classroom briefly, the platform adopted, the way to obtain and submit learning tasks, the possible forms of classroom activities, in order to make students have a clear understanding of the learning process and methods. Before the experiment, students were asked to form a study group of 3-6 people and choose the group leader. The flipped practice activities can be carried out as shown in Table 3.

Table 3. Flipped Classroom instructional design and practice table

\begin{tabular}{|c|c|c|c|}
\hline Time & & Teachers' tasks & Students' tasks \\
\hline $\begin{array}{l}\text { Before } \\
\text { class }\end{array}$ & $\begin{array}{l}\text { A week in } \\
\text { advance }\end{array}$ & $\begin{array}{l}\text { (a) Release learning resources and tasks on online learning } \\
\text { platforms; } \\
\text { (b) Guide students in the scene of independent learning; } \\
\text { (c) Monitor and urge effectively students to study through the } \\
\text { network platform; } \\
\text { (d) Feedback students' questions and submitted homework } \\
\text { timely; } \\
\text { (e) Summarize the problems that students encounter in the } \\
\text { learning process, and prepare for the lesson for the second time }\end{array}$ & $\begin{array}{l}\text { (a) Learn according to the } \\
\text { resources and tasks issued by the } \\
\text { teacher; } \\
\text { (b) Collaborate through the " } \\
\text { Learning Cell System"; } \\
\text { (c) Communicate and discuss } \\
\text { offline }\end{array}$ \\
\hline \multirow[t]{4}{*}{ In class } & $10 \mathrm{~min}$ & Teach knowledge points and answer questions & Question \\
\hline & $35 \mathrm{~min}$ & $\begin{array}{l}\text { (a) Release sharing/discussion/cooperation tasks; } \\
\text { (b) Give guidance to individual students or groups; } \\
\text { (c) Observe students' participation in class, evaluate and record }\end{array}$ & $\begin{array}{l}\text { Group collaboration } \\
\text { individual inquiry }\end{array}$ \\
\hline & $30 \mathrm{~min}$ & $\begin{array}{l}\text { (a) Guide students to show and report; } \\
\text { (b) Guide group mutual evaluation; } \\
\text { (c) Guide the group discussion }\end{array}$ & Group report \\
\hline & $15 \mathrm{~min}$ & Guide students to summarize and evaluate the class & Reflect and summary \\
\hline
\end{tabular}

\subsubsection{Teaching Practice Effect and Conclusion}

(1) Experiment results

This round aims to explore whether Flipped Classroom can improve students' subject consciousness and how it affects students' performance.

(a) Subject consciousness development

The t-test results of the subject consciousness are shown in Table 4. The test results show that the test probability of the significant difference is Sig=0.00, which is less than the significance level of 0.05 , confirming the significant difference between the two. The experimental class adopting the Flipped Classroom mode has significantly improved the subject consciousness.

Table 4. Independent sample T-test of subject consciousness in experimental class and control class

\begin{tabular}{|c|c|c|c|c|c|}
\hline & \multicolumn{2}{|c|}{ Levene's Test for Equality of Variances } & \multicolumn{3}{|c|}{ t-test for Equality of Means } \\
\hline & $\mathrm{F}$ & Sig. & Sig. (2-tailed) & Mean Difference & Std. Error Difference \\
\hline Equal variances assumed & 1.301 & .256 & .000 & $\begin{array}{l}-10.38262 \\
-1038262\end{array}$ & 2.03007 \\
\hline Equal variances not assumed & & & .000 & -10.38262 & \\
\hline
\end{tabular}

(b) Academic performance

Since the scores of the two classes all meet the normal distribution, independent sample t-test can be conducted on the corresponding data of the two classes. The results show that Sig $=0.588$, far higher than the significance level of 0.05 , confirming that there was no significant difference between the two. Therefore, although the average score of the experimental class is slightly higher than that of the control class $(85.9 / 84.7)$, there is no significant difference between the two classes.

\section{(2) Experiment summary}

Flipped Classroom has no obvious impact on students' performance, but it does bring significant changes to students' subject consciousness.

At the same time, some problems in Flipped Classroom teaching were also found in the process of teaching practice. (a) A small number of students showed a negative attitude towards Flipped Classroom and group collaboration, and they could not really participate in the discussion and exploration, and there was still a phenomenon of "free riding" in the group. (b) The use of online learning platform experience was not good. For people who use the platform for the first time, students were prone to get lost and experience the effect was not good, which also leaded to some people's negative feelings towards the whole course. (c) There were a lot of invalid discussions in the class. Some groups didn't really have much time to solve problems, and not many members contribute to solving problems.

The above phenomenon shows that some students are still accustomed to the traditional passive learning mode, and 
their subject consciousness is seriously insufficient.

\subsection{The Second Round of Teaching Practice}

\subsubsection{Research Object Selection}

For the problems existing in the experimental class in the first round, the authors decided to add online learning behavior detection and necessary feedback mechanisms in Flipped Classroom teaching activities; and to stimulate learners' subject consciousness with professional intervention and promote the development of subject consciousness by means of motivation stimulation, role awareness and group awareness. This round of research focuses on the following questions. (a) Whether students' subject consciousness has changed from the perspective of students' longitudinal development. (b) Whether students' subjective consciousness will have an impact on their performance.

In this experiment, only one class was used for vertical comparison, and the teaching practice was organized based on Information Processing Foundation. A total of 108 students participated in this round of teaching practice.

\subsubsection{Teaching Activities Implementation}

In order to ensure the smooth development of online learning behavior and feedback, this round was carried out on the "Beijing Normal University computer basic course teaching service platform". In addition, in view of the problems found in the first round, this teaching practice had some changes. (a) Add the guidance of learning methods to solve the problems encountered by students. (b) Guide students to conduct self-monitoring. (c) Guide group cooperation activities effectively. (d) Increase the teaching activities of "asking for answers". (e) Integrate of reporting and summarization.

The completed instructional design and implementation table of Flipped Classroom is shown in Table 5.

Table 5. The improved instructional design and implementation table of Flipped Classroom

\begin{tabular}{|c|c|c|c|}
\hline Time & & Teachers' tasks & Students' tasks \\
\hline $\begin{array}{l}\text { Before } \\
\text { class }\end{array}$ & $\begin{array}{l}\text { A week in } \\
\text { advance }\end{array}$ & $\begin{array}{l}\text { (a) Simplify learning resources and tasks on online learning } \\
\text { platforms; } \\
\text { (b) Develop learning methods guiding courses; } \\
\text { (c) Pay more attention to students' self-determined learning } \\
\text { path and self-reflection, which will be included in the usual } \\
\text { evaluation; } \\
\text { (d) Guide students in the scene of independent learning; } \\
\text { (e) Monitor and urge effectively students to study through } \\
\text { the network platform; } \\
\text { (f) Feedback students' questions and submitted homework } \\
\text { timely; } \\
\text { (g) Summarize the problems that students encounter in the } \\
\text { learning process, and prepare for the lesson for the second } \\
\text { time }\end{array}$ & $\begin{array}{l}\text { (a) Learn according to the resources and } \\
\text { tasks issued by the teacher; } \\
\text { (b) Collaborate through the "Beijing Normal } \\
\text { University computer basic course teaching } \\
\text { service platform"; } \\
\text { (c) Self-monitor the learning situation } \\
\text { according to the self-determined learning } \\
\text { path }\end{array}$ \\
\hline \multirow[t]{6}{*}{ In class } & $5 \mathrm{~min}$ & Teach knowledge points and answer questions & Question \\
\hline & $15-25 \mathrm{~min}$ & $\begin{array}{l}\text { (a) Release sharing/discussion/cooperation tasks; } \\
\text { (b) Give guidance to individual students or groups; } \\
\text { (c) Guide students to conduct role awareness, carry out } \\
\text { group discussion by using group division table and } \\
\text { self-assessment table; } \\
\text { (d) Observe students' participation in class, evaluate and } \\
\text { record; } \\
\text { (e) Focus on underperforming students, lead small groups } \\
\text { or coach teachers }\end{array}$ & Group collaboration or individual inquiry \\
\hline & $15-25 \mathrm{~min}$ & Discuss, debate, independent learning & Engage and reflect \\
\hline & $20 \mathrm{~min}$ & $\begin{array}{l}\text { (a) Guide students to show and report; } \\
\text { (b) Guide group mutual evaluation; } \\
\text { (c) Guide the group discussion }\end{array}$ & $\begin{array}{l}\text { (a) Group report; } \\
\text { (b) Reflect and summary }\end{array}$ \\
\hline & $15 \mathrm{~min}$ & $\begin{array}{l}\text { By asking questions, students are guided to sort out } \\
\text { knowledge and deepen understanding in the context of } \\
\text { questions. }\end{array}$ & Reflect and summary knowledge \\
\hline & $5 \mathrm{~min}$ & Summary & \\
\hline
\end{tabular}

\subsubsection{Teaching Experiment Effect and Conclusion}

(1) Experiment results

(a) Subject consciousness development

This practice explored the development of students' subject consciousness through the paired sample T-test of the total score and sub-score of the questionnaire questions before and after the test. The detailed report of the paired sample 
T-test is shown in Table 6.

As can be seen from Table 6, except for "self-consciousness", Sig values of both the total score and the dimensions of "practice consciousness" and "social consciousness" are less than 0.05, and the post-test scores are higher than the pre-test scores. This shows that before and after this round of teaching experiment, students' subjective consciousness has been significantly improved.

Table 6. The paired sample T-test of score of each dimension of subject consciousness before and after the test

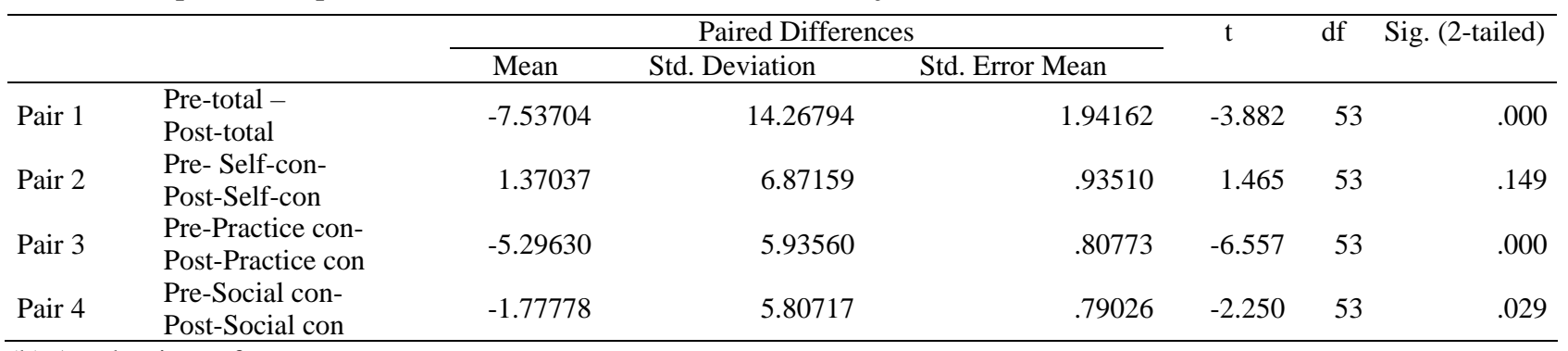

(b) Academic performance

In this round of teaching practice, students' grades are given jointly by the teacher and the course assistant. Considering that teachers and course assistants may give different scores for the same level of homework or performance in the grading process, but their evaluation concepts are consistent and their judgment on the merits of homework or performance is consistent; that is, from the perspective of statistics, the measure directly reflected by the rank of students' scores is reliable. Therefore, Wilcoxon rank sum test was used to test the overall distribution of subject consciousness and scores, and correlation samples were still used.

The test results show that $\mathrm{P}=0.116>0.05$, that is, the distribution difference between subject consciousness and grades is not significant, indicating that the performance of students' subject consciousness is consistent with their performance. When the student's subject consciousness enhances, the result also can increase correspondingly.

\section{(2) Experiment summary}

This experiment was carried out on the basis of the first experiment summary and reflection. Therefore, the preparation of course resources, the design and arrangement of course teaching activities were improved, and the experiment achieved good results. In this round of practice, since there is only one experimental class, the teacher can devote more energy to the observation and guidance of students, and find the problems of students and help solve them timely. After a semester of Flipped Classroom, students' subject consciousness has indeed improved. The analysis shows that the improvement of students' subjective consciousness can affect their grades. After the end of the course, the authors also found that the students generally have a higher evaluation on the course arrangement of this semester in the communication with the students, believing that this learning method can help them deepen their understanding and application of knowledge and skills, and the computer knowledge they have learned can be well transferred to other subjects.

\subsection{Improvement of Flipped Classroom Instructional Design}

In view of the problems in the first round, such as poor foundation, slow improvement, "free riding" phenomenon and low efficiency of group cooperation, teachers added learning method guidance and adopted a variety of monitoring methods in the second round. The second round showed that these measures and strategies adopted were indeed effective in avoiding the above problems. The optimized table is shown in the table 7. 
Table 7. Optimized table of flipped teaching strategy oriented on subject consciousness

\begin{tabular}{|c|c|c|c|c|}
\hline \multicolumn{2}{|c|}{$\begin{array}{l}\text { Subject consciousness } \\
\text { Flipped Classroom }\end{array}$} & $\begin{array}{l}\text { Self- } \\
\text { consciousness }\end{array}$ & Practice consciousness & Social consciousness \\
\hline \multirow{2}{*}{$\begin{array}{l}\text { Learning Stage } \\
\text { of New } \\
\text { Knowledge } \\
\text { Before Class }\end{array}$} & Independent learning & $\begin{array}{l}\text { Track network behavior; } \\
\text { Self-monitoring }\end{array}$ & & \\
\hline & Collaborate learning & $\begin{array}{l}\text { Role awareness; } \\
\text { Self-evaluation table }\end{array}$ & $\begin{array}{l}\text { Role assignment; } \\
\text { Enhanced external } \\
\text { motivation }\end{array}$ & $\begin{array}{l}\text { Role assignment; Role } \\
\text { awareness }\end{array}$ \\
\hline \multirow[t]{3}{*}{$\begin{array}{l}\text { Sharing Stage in } \\
\text { Class }\end{array}$} & Group discuss & $\begin{array}{l}\text { Role awareness; } \\
\text { Self-evaluation table }\end{array}$ & $\begin{array}{l}\text { Role assignment; } \\
\text { Enhanced external } \\
\text { motivation }\end{array}$ & $\begin{array}{l}\text { Role assignment; } \\
\text { Role awareness }\end{array}$ \\
\hline & Group report & $\begin{array}{l}\text { Reward the initiative; } \\
\text { Designate the reporter }\end{array}$ & $\begin{array}{l}\text { Encourage innovation; } \\
\text { Designate the reporter }\end{array}$ & Team collaboration \\
\hline & Evaluation & $\begin{array}{l}\text { Reflect and self- } \\
\text { evaluation }\end{array}$ & $\begin{array}{l}\text { Mutual- evaluation and } \\
\text { questioned }\end{array}$ & $\begin{array}{l}\text { Mutual- evaluation and } \\
\text { questioned }\end{array}$ \\
\hline \multirow[t]{2}{*}{ Promoting Stage } & Question & Reasonable question & & \\
\hline & Teacher summary & Direct reflection & & \\
\hline
\end{tabular}

\section{Conclusion}

This study analyzed the existing Flipped Classroom teaching mode through literature research, case analysis and other ways, and discussed the connotation and essence of Flipped Classroom. The authors thought that the inherent reason that Flipped Classroom can improve students' learning initiative and enthusiasm, promote the student collaboration and innovation ability is the development of the students' subject consciousness. Therefore, this study integrated the relevant theory of subject consciousness and the existing Flipped Classroom teaching mode, proposed the Flipped Classroom teaching mode and teaching activity strategy oriented on subject consciousness cultivation, and verified the mode in the public computer courses of the university. The practice results showed that the teaching mode and strategy are helpful to achieve the expected teaching objectives. No matter from horizontal or vertical comparison, Flipped Classroom can indeed cultivate and improve students' subject consciousness, and have an impact on students' overall academic performance. Based on two rounds of empirical research, the following three results are obtained.

(1) Flipped Classroom is an effective means to cultivate students' subject consciousness

After a comprehensive analysis of the existing Flipped Classroom theories, teaching modes and teaching cases, this study introduced the concept of subject consciousness into Flipped Classroom and proposed that what is really beneficial to students is the cultivation and improvement of their subject consciousness. After combining subject consciousness with Flipped Classroom, the authors proposed a Flipped Classroom teaching mode oriented on subject consciousness, and designed and verified the flipped teaching activities and strategies based on this mode in detail, so as to provide references for the subsequent relevant researches.

(2) Integrate the subject consciousness of different dimensions into teaching activities

This study dissected the subject consciousness into three dimensions: self-consciousness, practice consciousness and social consciousness. This study analyzed what kind of subject consciousness was embodied in different teaching activities and integrated the cultivation of subject consciousness into specific teaching activities.

(3) Put forward the strategy of cultivating subject consciousness in specific teaching activities, and formed a stable teaching mode

For specific teaching activities, the strategies for the subject consciousness were designed and applied in practice to verify the effectiveness of the strategies after analyzing the role of the teaching activity and the subject consciousness embodied in it. The usage of these strategies effectively urged students to pay attention to and reflect on their learning state at all times, and returned their learning feelings and progress to themselves rather than to the teachers, so that students can give full play to their subjectivity and complete the transformation from the traditional classroom to the subjectivity classroom in which students participate.

\section{Acknowledgements}

We would like to thank all the teachers and students who have supported our teaching practice. It is your enthusiasm and encouragement that has always supported us. Thanks to Faculty of Education of Beijing Normal University for providing good support and guarantee for our research. Thank all of you!

\section{References}

Bill, T. (2012). The Flipped Classroom. EDUCATION NEXT, 12, 82-83.

Clyde, F. H., \& Nancy, A. (2013). Case Studies and the Flipped Classroom. Journal of College Science Teaching, 42(5), 
$62-67$.

Daim Z. X., \& Liu, J. (2010). Functional analysis of the hierarchical structure of students' subjective development. Journal of Jingdezhen College, 25(02), 79-80.

Huang, X. H. (2007). The research and practice of subjectivity education in high school biology teaching under the new curriculum standard. Guangxi Normal University.

Ma, X. L., Zhao, G. Q., \& Wu, T. (2013). An empirical study of flipped classroom teaching in university information technology public courses. Journal of Distance Education, 1, 79-85.

Mark, F. (2012). Flipping Excel. ISSN, (29): 1-11. https://doi.org/10.1007/s11621-012-0105-x

Pei, D. N. (2000). Main body participation teaching strategies - - one of the main body education, developing teaching laboratory study. Subject Education, (01), 8-11+49.

Robert, T. [2010]. Inverting the Linear Algebra Classroom. [DB/OL]. http://prezi.com/dz0rbkpy6tam/inverting-the-linear-algebra-classroom.

Thomson, C. K., Masumi-so, H., \& Osho, F. (2001). Meeting the challenge in language for specific purposes: The incorporation of sociolinguistics and learner autonomy into course design. Japanese studies, 21(1), 85-98. https://doi.org/10.1080/10371390120048777

Victori, M., \& Lockhart, W. (1995). Enhancing metacognition in self-directed language learning. System, 23(2), 223-234. https://doi.org/10.1016/0346-251X(95)00010-H

Xu, J. F., \& Zhan X. H. (2004). A review of the research on learner autonomy at home and abroad. Foreign Language World, 04, 2-9.

Zhang, J. Y. (2002). Try to analyze the connotation of subject consciousness. Journal of Tianzhong, 06, 5-9.

Zhang, Y. (2013). Research on the construction of the main participatory classroom teaching model of junior middle school English. Jiangxi Normal University.

Zheng, J. H., Yu, S. W., \&Nan, S. Y. (2009). Reconstructing the connotation of "student subjectivity". Journal of Hebei Polytechnic University (Social Science Edition), 9(03), 63-65+69.

\section{Copyrights}

Copyright for this article is retained by the author(s), with first publication rights granted to the journal.

This is an open-access article distributed under the terms and conditions of the Creative Commons Attribution license which permits unrestricted use, distribution, and reproduction in any medium, provided the original work is properly cited. 